\title{
高齢者における咳嗽時最大呼気流量と 胸腹部可動性の関連
}

\author{
Association of Cough Peak Flow with Chest and \\ Abdominal Wall Mobility in Older Adults
}

金子 秀雄 ${ }^{1)}$ 鈴木 あかり ${ }^{1)}$

Hideo KANEKO, RPT, $\mathrm{PhD}^{1)}$, AKARI SUZUKI, RPT, $\mathrm{PhD}^{1)}$

1) Department of Physical Therapy, School of Health Sciences at Fukuoka, International University of Health and Welfare: 137-1 Enokizu, Okawa-shi, Fukuoka 831-8501, Japan TEL+81944-89-2000 E-mail: hkaneko@iuhw.ac.jp

Rigakuryoho Kagaku 36(2): 197-201, 2021. Submitted Oct. 12, 2020. Accepted Nov. 17, 2020.

\begin{abstract}
Purpose] This study investigated the association between cough peak flow and the chest and abdominal wall mobility of older adults. [Participants and Methods] Cough peak flow, chest and abdominal wall mobility (upper chest, lower chest, and abdomen) of 188 community-dwelling older adults (63 males, 125 females) were assessed using the breathing movement scale and respiratory function (forced vital capacity, forced expiratory volume in $1 \mathrm{~s}$, and maximum inspiratory and expiratory pressures). [Results] The female participants had lower values of all the measurement items except age, body mass index, and upper chest wall mobility. In multiple regression analyses by sex, the value of the abdominal scale was a significant predictor of cough peak flow in both sexes. [Conclusion] This study provides evidence that cough strength may be associated with abdominal wall mobility in ambulatory community-dwelling older adults.
\end{abstract}

Key words: older adults, cough peak flow, chest and abdominal wall mobility

要旨:〔目的〕本研究の目的は地域在住高齢者における咳嗽時最大呼気流量と胸腹部可動性の関連を明らかにすること 〔対象と方法〕地域在住高齢者 188 名（男性 63 名，女性 125 名）を対象に咳嗽時最大呼気流量，胸腹部可動性とし て呼吸運動評価スケールによる上部胸郭・下部胸郭・腹部スケール值, 呼吸機能として努力性肺活量, 一秒率, 最大 吸気圧，最大呼気圧を測定した。〔結果〕男女の比較では，年齢，Body Mass Index，上部胸郭スケール值を除き，女 性が有意な低值を示した，重回帰分析において咳嗽時最大呼気流量の有意な子測因子は，男女ともに腹部スケール值 であった。〔結語〕歩行が自立した地域在住高齢者における腹部可動性は咳嗽時最大呼気流量に関連することが示唆 された.

キーワード : 高齢者, 咳嗽時最大呼気流量, 胸腹部可動性

1) 国際医療福祉大学 福岡保健医療学部 理学療法学科 : 福岡県大川市榎津 137-1 ( ₹ 831-8501) TEL 0944-89-2000

受付日 2020 年 10 月 12 日 受理日 2020 年 11 月 17 日 


\section{I.はじめに}

高齢者の肺炎は誤嚥性肺炎が大半であり 1), 四燕下機能 低下に咳嗽機能低下が重なることで肺炎発症リスクは増 大する。そのため, 近年は誤嚥性肺炎予防に対する咳嗽 機能の重要性が指摘されている2), 咳嗽時最大呼気流量 (cough peak flow : 以下, CPF) は, 咳嗽機能の臨床指 標として利用され, 嚥下機能低下者の肺炎発症に影響を 及ぼすことが知られている ${ }^{3)}$. ゆえに, 四燕下機能が低下 しやすい高齢者では, 肺炎発症リスクを抑えるため CPFを保つことが望まれる。

高齢者の CPFに関連する因子は，呼吸機能（努力性 肺活量, 呼吸筋力, 胸郭可動性), 運動機能, 身体活動 からみたとき, 努力性肺活量と吸気筋力になる4)。特に 努力性肺活量は CPFに直接的な影響を与えることか ら 5), 加齢に伴う努力性肺活量の低下は CPF を低下に つながる. 加えて, 高齢者の努力性肺活量は呼吸筋力よ り胸郭可動性に影響されやすいことから 6), CPF の低下 を予防するには胸郭可動性との関連を理解することが必 要と考えられる. CPF と胸郭可動性に関する研究 7,8) で は，若年者から高齢者を対象に，第 10 胁骨部の胸郭拡 張差が CPF に関連したことを報告している7). しかし, 高齢者のみを対象にした先行研究はなく, 同様な関連が あるかは明らかでない。

胸郭可動性は, 一般に, 胸郭拡張差によって評価され ている。しかし, 努力性肺活量と胸郭可動性の関連は呼 吸運動評価スケールを用いて検証されている ${ }^{6)}$ 。このス ケールは胸腹部の深呼吸運動（上部胸郭，下部胸郭，腹 部）を 0 〜 の 9段階で表した指標である. 健常者デー 夕によって定義されたスケールは, 呼吸運動の異常性や 可動性低下の判断に利用される9). 測定姿勢は背臥位に 限定されるが, ペンサイズの測定器具を胸腹部の定点に あて呼吸運動方向に保持するため, 着衣の影響を受けに くく, 測定の信頼性と妥当性はともに保たれる 10)。 そ れゆえ, 呼吸運動評価スケールは胸郭可動性評価に適し ており,このスケールと CPFの関連を明らかにするこ とは, 高齢者における $\mathrm{CPF}$ 維持や改善に向けたアプロー チを検討するための一助になると考えられる。

そこで本研究の目的は, 地域在住高齢者を対象とした $\mathrm{CPF}$, 努力性肺活量, 呼吸筋力, 呼吸運動評価スケール を用いた胸腹部可動性の調査から, CPF と胸腹部可動 性の関連を検証することとした。

\section{II. 対象と方法}

\section{1. 対象}

本研究におけるデー夕は, 2014２017 年に地域在住 高齢者に対する呼吸機能調査を目的とした測定会によっ て収集された。介護予防事業の一環として公民館で実施
される自主活動の参加者に対して募集を行い，測定を実 施した。研究協力に同意の得られた 65 歳以上の参加者 223 名は，すべて歩行が自立していた，対象者のうち， 肥満 (Body Mass Index $>30 \mathrm{~kg} / \mathrm{m}^{2}$ ) (6 名), 呼吸器疾 患 $(1$ 名), 気流制限が認められた者 (22 名), 測定実 施が困難であった者（6名）は除外した。肥満は CPF の関連因子である努力性肺活量に影響を及ぼすこと ${ }^{11)}$, 気流制限は CPF に直接的な影響が想定されることから, これらを除外基準に含めた，対象者の基礎疾患は服薬状 況に関するアンケートから判断した。最終的に 188 名 (年齢 $78 \pm 6$ 歳: 平均 \pm 標準偏差, 男性 63 名, 女性 125 名）を分析対象とした。本研究は所属施設の倫理審 査委員会の承認（15-Ifh-02）を得た後に実施した。

\section{2. 方法}

CPF は, フェイスマスクを接続したピークフローメー 夕（アセス，レスピロニクス社製）を用いて測定した。 参加者の鼻と口を覆うようにフェイスマスクを密着させ, 最大吸気位からできるだけ強い咳嗽を行わせた。手順を 説明し, 必要に応じて練習を行ったのち測定を 3 回実施 し，最大值を採用した。 中高齢者における自己排痰に必 要な CPF のカットオフ值である $2401 / \mathrm{min}^{12)}$ 未満を CPF 低下とした。

努力性肺活量, 対標準努力性肺活量, 一秒率の測定に は，携帯型スパイロメータ（Spirobank, MIR 社製）と 使い捨てのマウスピースを用いた。座位にて鼻およびロ 角から息が漏れないようにしながらマウスピースをくわ えさせ，最大吸気位から努力呼気を 6 秒間持続させた。 手順を説明したのち, 適切に測定できた 3 回の測定結果 から最大值を採用した。拘束性換気障害は気流制限がな く，予測值下限 13) を下回る努力性肺活量と定義した。

胸腹部可動性は, 深呼吸時の呼吸運動を呼吸運動評価 スケールで評価した。深呼吸時における呼吸運動の大き さは, 先行研究 14)に準じて呼吸運動測定器を用い, 0 8 の 9 段階で測定した。深呼吸時の呼吸運動の大きさは, 呼吸運動なしが 0 , 正常上限值を超える值が 8 を意味し, 正常下限值未満である 4 未満は可動性低下と定義した。 測定部位は, 両側の上部胸郭と下部胸郭および腹部の 5 力所であるが, 胸郭運動に明らかな左右差がなければ 右側のみを測定した。上部胸郭と下部胸郭の測定部位は それぞれ鎖骨内側 $1 / 3$ を通る第 3 胁骨と第 8 肋骨, 腹部 は剣状突起下端と臍部の中点とした。呼吸運動測定器を 各測定部位にあて最大呼気位から最大吸気位までの呼吸 運動の大きさを測定した。それぞれの測定部位で深呼吸 を2 回実施し最大值を記録した。

呼吸筋力は, 口腔内圧計 (MicroRPM, Carefusion 社 製）を用いて最大吸気圧，最大呼気圧を測定した。座位 にて $2 \mathrm{~mm}$ のリーク孔のあるマウスピースをくわえさせ， 残気量位から最大吸気努力および全肺気量位から最大呼 
気努力を行わせた。吸気努力時は鼻から空気が抜けない ように，呼気努力時は口角から空気が漏れないようにさ せた。練習を行ったのち, 適切に測定できた 3 回の測定 結果から最大值を採用した。

得られたデー夕は，男女別に平均值と標準偏差または 中央值と範囲で表した。また，基礎疾患，CPF 低下， 拘束性換気障害, 可動性低下を示した対象者数を計算し た。正規性の検定には Shapiro-Wilk 検定を用い, 男女 別の比較に対応のない $\mathrm{t}$ 検定または Mann-Whitneyの $\mathrm{U}$ 検定， $\chi^{2}$ 検定またはFisherの正確確率検定を用いた。 $\mathrm{CPF}$ と胸腹部可動性の関連は男女別に重回帰分析（ス テップワイズ法）を用い, CPF を従属変数, 上部胸郭, 下部胸郭, 腹部のスケール值を独立変数, 年歯, 身長, 体重を共変量とした。各スケール值は多重共線性（r > 0.7）がないことを確認した後に独立変数として採用し た。有意水準は $5 \%$ とした。統計分析はSPSS ver.24 (IBM 社製) を使用した。

\section{III. 結 果}

測定結果を表 1 に示す。基礎疾患は，高血圧症 66 名 (35\%), 糖尿病 18 名 $(10 \%)$, 脂質異常症 16 名 (9\%),
心疾患 11 名 (6\%) であり, 高血圧症の保有者数は男性 より女性が有意に多かった。CPF 低下者数は 46 名 （24\%）であり，その割合は男性より女性が有意に高值 であった（それぞれ $11 \% ， 30 \%$ )。拘束性換気障害を示 した対象者は 46 名 (24\%) であり，男女の割合に有意 差はなかった（それぞれ $21 \% ， 26 \%$ ）。胸腹部の可動性 低下（スケール值＜4）を示した対象者は，上部胸郭 73 名 (39\%), 下部胸郭 101 名 (54\%), 腹部 31 名 (16\%) であり，下部胸郭が最も多かった。男女別の割合は，男 性では上部胸郭 $33 \%$ ，下部胸郭 $41 \%$ ，腹部 5\%，女性 では上部胸郭 $42 \%$, 下部胸郭 $60 \%$, 腹部 $22 \%$ を示し, 下部胸郭掞よび腹部の可動性低下者数は男性より女性で 有意に高值であった。その他の測定項目における男女別 比較では, 年齢, Body Mass Index, 対標準努力性肺活量, 上部胸郭スケール值を除いたすべての項目において男性 より女性が有意な低值を示した。

重回帰分析では, 各スケール值の多重共線性は認めら れなかったため，3つのスケール值を独立変数とした分 析を行った。得られた重回帰式は男女ともに有意であっ たが，決定係数は男性 0.27 ，女性 0.17 であり予測精度 は低かった。そして, CPFの有意な予測因子として男 女ともに腹部スケール值が抽出された（表 2).

表 1 対象者の属性と呼吸機能, 咳嗽時最大呼気流量, 胸腹部可動性

\begin{tabular}{|c|c|c|}
\hline & 男性（n=63） & 女性（n=125） \\
\hline 年齢（歳） & $78 \pm 6$ & $78 \pm 6$ \\
\hline 身長（m） & $1.61 \pm 0.06$ & $1.50 \pm 0.06^{* \dagger}$ \\
\hline 体重（kg） & $59.6 \pm 7.5$ & $51.9 \pm 8.5^{* \dagger}$ \\
\hline Body Mass Index $\left(\mathrm{kg} / \mathrm{m}^{2}\right)$ & $23.1 \pm 2.3$ & $23.1 \pm 3.5$ \\
\hline 高血圧症 & 14 & $52 *$ \\
\hline 糖尿病 & 7 & 11 \\
\hline 脂質異常症 & 2 & 14 \\
\hline 心疾患 & 4 & $7 \pm$ \\
\hline 努力性肺活量（1） & $2.87 \pm 0.63$ & $1.97 \pm 0.46^{*}$ \\
\hline 対標準努力性肺活量（\%) & $90.7 \pm 16.7$ & $87.3 \pm 18.5^{\dagger}$ \\
\hline 拘束性換気障害 (n) & 13 & $33 \neq$ \\
\hline 一秒率（\%） & $77.1 \pm 6.5$ & $80.3 \pm 6.6^{*}$ \\
\hline CPF $(1 / \mathrm{min})$ & $361 \pm 108$ & $275 \pm 75^{* \dagger}$ \\
\hline CPF 低下（n） & 7 & $37 * 末$ \\
\hline 最大吸気圧（ $\mathrm{cmH}_{2} \mathrm{O} ）$ & $57.7 \pm 25.1$ & $44.3 \pm 20.5^{* \dagger}$ \\
\hline 最大呼気圧（ $\mathrm{cmH}_{2} \mathrm{O} ）$ & $88.6 \pm 31.5$ & $62.6 \pm 25.2 *$ \\
\hline 上部胸郭スケール（0～8） & $4(2 \sim 7)$ & $4(2 \sim 7)^{\dagger}$ \\
\hline 可動性低下（n） & 21 & $52 末$ \\
\hline 下部胸郭スケール（0～8） & $4(2 \sim 7)$ & $3(1 \sim 7) * \dagger$ \\
\hline 可動性低下（n） & 26 & $75^{*}+$ \\
\hline 腹部スケール（0～8） & $6(1 \sim 8)$ & $5(1 \sim 8) * \dagger$ \\
\hline 可動性低下（n） & 3 & $28 * \ddagger$ \\
\hline
\end{tabular}

平均值 \pm 標準偏差または中央值 (範囲). CPF：咳嗽時最大呼気流量, 可動性低下：スケール值 $<4, \mathrm{CPF}$ 低下： CPF $<2401 / \mathrm{min} . *$ : $\mathrm{p}<0.05$, $\dagger$ : Mann-Whitney のU 検定, $\ddagger$ : Fisher の正確確率検定. 
表 2 咳嗽時最大呼気流量に対する重回帰分析の結果

\begin{tabular}{ccc}
\hline & 標準偏回㷌係数 & 決定係数 \\
\hline 男性 $(\mathrm{n}=63)$ & & \\
年齢 & $-0.29^{*}$ & 0.27 \\
身長 & 0.09 & \\
体重 & $-0.34^{*}$ & \\
腹部スケール & $0.33^{*}$ & \\
女性 $(\mathrm{n}=125)$ & & \\
年齢 & $-0.25^{*}$ & 0.16 \\
身長 & 0.09 & \\
体重 & -0.05 & \\
腹部スケール & $0.20 *$ & \\
\hline
\end{tabular}

年齢, 身長, 体重を共変量とし, ステップワイズ法を 用いた。 $*: \mathrm{p}<0.05$.

\section{IV. 考 察}

本研究において，歩行が自立した高齢者の $24 \% に$ $\mathrm{CPF}$ 低下が認められ，CPF 低下者は呼吸機能が低い女 性に多いことがわかった。そして，高齢者のCPFは， 男女ともに腹部可動性と関連することが示された。 Yawata 5 7) は, 若年者から高齢者における CPF が第 10 肋骨部の胸郭拡張差と関連があったことを報告して いる. この研究の評価指標は, 測定部位の高さ (水平位) が腹部スケールと同じレベルにあり, 腹部呼吸運動を反 映する指標である。この観点から考えると本研究の結果 は, Yawata 5 7) の研究と一致する. しかし, この研究 7) は，幅広い年齢層を対象にしているにもかかわらず，年 齢や体型の影響が考慮されていないため, 単純に比較す ることはできない.

胸郭可動性は加齢に伴い低下する 15,16)。特に，円背 変形のような加齢的変化は, 胸郭可動性と肺活量を低下 させる 17)。本研究の対象者においても約半数が下部胸 郭可動性低下を示し, 拘束性換気障害は 4 人に 1 人の割 合で認められた，腹部可動性低下の割合がおよそ6人に 1 人であったことを踏まえると, 胸郭可動性が肺活量の 加齢的変化に影響していることは明らかである6). その ため, 胸郭可動性が低下した高齢者では腹部可動性を利 用して肺容量を確保し, 肺活量を維持していると考えら れる。実際, 我々の先行研究 6) では, 胸郭可動性低下 を認めても胸腹部スケール值の合計が一定水準以上あれ ば，ほとんどの高齢者は拘束性換気障害と判断されない ことを確認している。

肺活量が保たれていれば，咳嗽初期に十分な吸気量が 確保できる。大きな吸気量は呼気筋を伸張させて呼気時 の張力発生に有利に作用し, 高い CPF を発揮させる ${ }^{18)}$. そのため, 本研究における CPF と腹部スケール值の関 連は，高齢者では咳嗽時の吸気量確保に腹部可動性を利
用していることが推測される．腹部可動性は横隔膜運動 を反映しており ${ }^{19)}$, この運動には横隔膜と腹筋群の拮 抗的な働きが必要となる。そして, 腹筋群は咳嗽の圧縮 相における胸腔内圧上昇に欠かせない筋でもある。した がって, 咳嗽の吸気相と圧縮相に必要な横隔膜および腹 筋群の活動が腹部可動性に反映されることで, CPF と の関連が導き出された可能性がある。この点に関しては 推測の域を出ないが, いずれにしても, 今回の結果は, 胸郭可動性が低下しやすい高齢者の CPF に腹部可動性 が有利に作用することを示すものと考えられる.

下部胸郭および腹部スケール值は, 男性に比べ女性で 低值を示した。これは先行研究と同様の結果 15)であり, 努力性肺活量や呼吸筋力と同様，性別や体型による影響 が考えられる。結果として, 努力性肺活量および吸気筋 力との関連を裏付けるように女性の CPF は低值を示し た。ゆえに，特に胸郭可動性の低下した女性に対しては， CPF の低下を予防する観点から, 腹部可動性に留意し て努力性肺活量や呼吸筋力を維持させることが大切にな ると考えられる。

以上のように, 本研究で得られた CPF と腹部可動性 の関連は, 胸郭可動性が低下した高齢者において腹部可 動性が CPF を保つために必要な要素の一つであること を示唆する. 加齢に伴う呼吸機能の低下は CPF 低下を 助長する可能性が高いことから, 胸腹部可動性を考慮す ることで呼吸機能が維持され，CPF 低下予防につなげ られるかは今後の課題と考えられる.

本研究の限界として, 今回の結果は歩行が自立した地 域在住高齢者を対象に得られたものであり, 歩行が困難 となり介護が必要となった高齢者においても同様な結果 が得られるかは不明である。また, 本研究は横断的な調 査であることから, CPF と胸腹部可動性の因果関係を 明らかにすることはできない。しかし， CPF，努力性肺 活量, 胸腹部スケール值の関連4) を踏まえると, 腹部 可動性は努力性肺活量を介して CPF に影響しているこ とが考えられる。これらの関連を検証することは本研究 の目的ではないが, CPF と胸腹部可動性の関連を明ら かにするためには, さらに縦断的調査や介入研究を行う 必要があるであろう。

利益相反 開示すべき利益相反はない.

\section{引用文献}

1) Teramoto S, Fukuchi Y, Sasaki H, et al. Japanese Study Group on Aspiration Pulmonary Disease: High incidence of aspiration pneumonia in community- and hospital-acquired pneumonia in hospitalized patients: a multicenter, prospective study in Japan. J Am Geriatr Soc, 2008, 56: 577-579.

2) Ebihara S, Sekiya H, Miyagi M, et al.: Dysphagia, dystussia, and aspiration pneumonia in elderly people. J Thorac Dis, 
2016, 8: 632-639.

3) Bianchi C, Baiardi P, Khirani S, et al.: Cough peak flow as a predictor of pulmonary morbidity in patients with dysphagia. Am J Phys Med Rehabil, 2012, 91: 783-788.

4) Kaneko H, Suzuki A, Horie J: Relationship of cough strength to respiratory function, physical performance, and physical activity in older adults. Respir Care, 2019, 64: 828-834.

5) 金子秀雄, 出利葉ゆうき, 川波奈緒・他 : 胸郭運動制限が 咳嗽時最大呼気流量と努力性肺活量に及ぼす影響. 理学療 法科学, 2018, 33: 743-746.

6) Kaneko H, Suzuki A: Effect of chest and abdominal wall mobility and respiratory muscle strength on forced vital capacity in older adults. Respir Physiol Neurobiol, 2017, 246: 47-52.

7) Yawata A, Tsubaki A, Yawata H, et al.: Voluntary cough intensity and its influencing factors differ by sex in community-dwelling adults. Ther Adv Respir Dis, 2017, 11: 427-433.

8) 坦内優芳, 藤原麻子, 河原由梨香 - 他 : 中高齢者の随意的 咳嗽力に関連する因子. 日本呼吸ケア・リハビリテーショ ン学会誌, 2015, 25: 272-275.

9) Kaneko H, Horie J, Ishikawa A: New scale to assess breathing movements of the chest and abdominal wall: preliminary reliability testing. J Phys Ther Sci, 2015, 27: 1987-1992.

10) Kaneko H: Assessing the reliability and validity of a newly developed breathing movement measuring device. J Phys Ther Sci, 2013, 25: 425-429.

11) Littleton SW: Impact of obesity on respiratory function. Respirology, 2012, 17: 43-49.
12) 山川梨絵, 横山仁志, 渡邊陽介 - 他 : 排痰能力を判別する cough peak flowの水準一中高齢患者における検討一. 人工 呼吸, 2010, 27: 260-266.

13) Kubota M, Kobayashi H, Quanjer PH, et al. Clinical Pulmonary Functions Committee of the Japanese Respiratory Society: Reference values for spirometry, including vital capacity, in Japanese adults calculated with the LMS method and compared with previous values. Respir Investig, 2014, 52: 242250.

14) 金子秀雄, 木庭知美, 徳永理紗：女子学生における非特異 的慢性腰痛の有無による呼吸機能の違い. 理学療法科学, 2016, 31: 799-804.

15) Kaneko H, Horie J: Breathing movements of the chest and abdominal wall in healthy subjects. Respir Care, 2012, 57: 14421451.

16) Verschakelen JA, Demedts MG: Normal thoracoabdominal motions. Influence of sex, age, posture, and breath size. Am J Respir Crit Care Med, 1995, 151: 399-405.

17) Culham EG, Jimenez HA, King CE: Thoracic kyphosis, rib mobility, and lung volumes in normal women and women with osteoporosis. Spine, 1994, 19: 1250-1255.

18) Smith JA, Aliverti A, Quaranta $M$, et al.: Chest wall dynamics during voluntary and induced cough in healthy volunteers. J Physiol, 2012, 590: 563-574.

19) 金子秀雄, 池高和典, 浦川涼人・他：簡易器具を使った腹 部呼吸運動測定による横隔膜運動の推定. 理学療法科学, 2017, 32: 359-363. 